
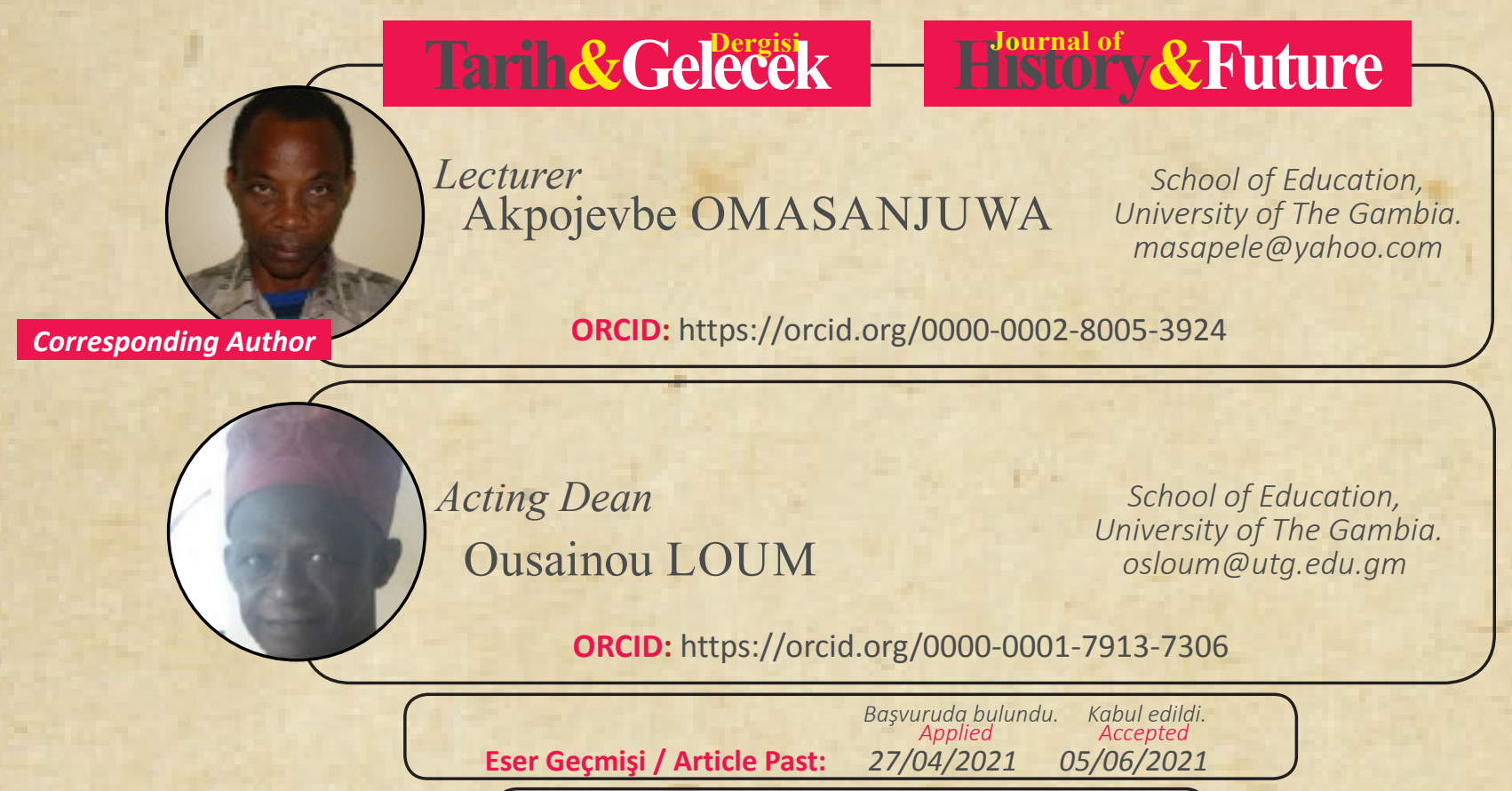

Indexed by

ERIHPUINS

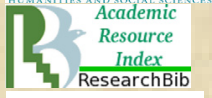

Ri $\mathbf{S}$ A $M$

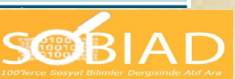

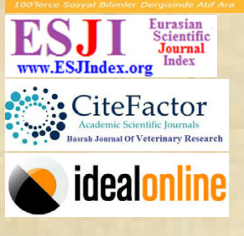

Araştırma Makalesi

DOI: http://dx.doi.org/10.21551/jhf.928700

Research Paper

Orjinal Makale / Orginal Paper

\title{
A Chronicle of The Gambia Prison System
}

\author{
Kroniklerde Gambiya Hapishane Sistemi
}

\begin{abstract}
The article addresses an aspect of prison condition in The Gambia since 1821, with the purpose of negating the calls for reforms of the system. Through qualitative analysis of primary and secondary sources, the chronology of the system was outlined and findings shows that the ramshackle condition of the facilities has no resemblance with those in Britain, especially Pentonville Prison of 1842 which was the standard prison in Britain and some of her colonies. Several reasons account for the neglect the institution has suffered since the colonial era. Apart from the shoestring budgetary allocations to the prisons, another factor among others is the ulterior motives of the colonial and post-colonial administrators using the facilities to keep potential mischief makers at bay by neglecting the penological principles governing prison administration. This offered the scanty European population and their successors protection from suspected mischief-makers, a tactic that could be interpreted as being tough on crime. The article recommended the phasing out of the prison system. In its place, an educational institution under the education ministry should replace the prisons.
\end{abstract}

Key words: Prisons, The Gambia, Human Rights, Colonial rule, penology.

ATIF: OMASANJUWA Akpojevbe, LOUM Ousainou, "Kroniklerde Gambiya Hapishane Sistemi", Tarih ve Gelecek Dergisi, 7/2 (Haziran 2021), s. (758-789) 


\section{$\ddot{O} z$}

Makale, sistemde reform çağrılarını reddetmek amacıyla 1821'den beri Gambiya'daki hapishane koşullarının bir yönüne değiniyor. Birincil ve ikincil kaynakların niteliksel analizi yoluyla, sistemin kronolojisi ana hatlarıyla açıklandı ve bulgular, tesislerin harap durumunun İngiltere'dekilerle, özellikle Britanya' daki standart hapishane olan 1842 Pentonville Hapishanesi ve onun bir kısmıyla benzerlik göstermediğini gösteriyor. koloniler. Kurumun sömürge döneminden beri yaşadığı ihmalin birkaç nedeni var. Hapishanelere kısıtlı bütçe tahsisatlarının yanı sıra, diğer faktörlerin yanı sıra, sömürge ve sömürge sonrası idarecilerin hapishane idaresini düzenleyen penolojik ilkeleri ihmal ederek potansiyel haylazları uzak tutmak için tesisleri kullanmalarının gizli nedenleri. $\mathrm{Bu}$, yetersiz Avrupalı nüfusu ve onların haleflerini şüpheli haydutlardan koruma sağladı; bu, suç için zor olarak yorumlanabilecek bir taktikti. Makale cezaevi sisteminin aşamalı olarak kaldırılmasını tavsiye ediyordu. Onun yerine, eğitim bakanlığına bağlı bir eğitim kurumu cezaevlerinin yerini almalıdır.

Anahtar kelimeler: Hapishane, Gambiya, İnsan Hakları, Sömürge kuralı, penoloji

\section{Introduction}

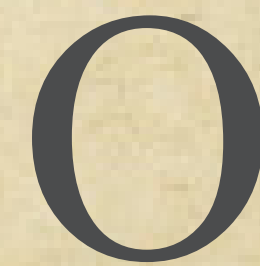

n January 18, 2019 The Gambia Truth, Reconciliation, and Reparation Commission went on a guided tour to acquaint its members with conditions at a prison facility at Mile 2, The Gambia. ${ }^{1}$ The effort stem from its mandate to investigate alleged human rights violations levelled against a former president, Yayah Jammeh, who governed the country from 1994 till 2016. Members of the commission were appalled while corroborating the gory accounts of witnesses at their previous sittings with the first hand experiences they were acquiring at the moribund facility. The decay of the antiquated dungeon was beyond thought. Since attaining independence from Britain in 1965, the penal system including that at Mile 2, which the colonialists banqueted the country remained in a derelict state, long before their departure. The infrastructure was constructed in 1920, part of the public buildings that studded the emerging city of Bathurst (later renamed Banjul) founded in 1816. At its inception in 1821, while it was located at McCarthy Square in the city centre, the institution was run by the sheriff, an appointee of the colonial governor to whom he was answerable. ${ }^{2}$ He however did not live in the yard, rather a gaoler was appointed to take residence there and watch over daily affairs. At night, only the gaoler and the principal turnkey (after 1853) remained while the constables retire home after knockoff time. ${ }^{3}$ Undisputedly, the prison conditions were out of tune with what obtained in the metropole.

The public as well was astounded at the dilapidated state of the colonial legacy they have lived with for a century. In suppressing dissenting voices to foreign rule, besides maintaining order,

\footnotetext{
1 https://youtu.be/do1PJAOU0NU?t=235

2 Park J. Matthew Heart Of Banjul: The History Of Banjul, The Gambia, 1816 -1965, A Dissertation Submitted to Michigan State University in partial fulfilment of the requirements for the degree of HistoryDoctor of Philosophy. (2016).

Ibid, 3.
} 
the facility was among the tools the colonial government put to use. Although prisons in Britain of the time had shortfalls in enforcing penological goals, they however metamorphosed through imbibing the evolving reformist ideas ameliorating hard-hitting penal conditions. However, in The Gambia, as in other British West African colonies, penal goals were propped by colonial aspirations of domination, repression, intimidation, deterrence and exploitation, and was shielded from the reforms made impermeable to her. ${ }^{4}$ That explains why colonial subjects perceived to be constituting nuisance to the colonial agenda were adjudged unfit to benefit from reformist European ideas.

During the era under review, obstacles impeding improvements of the penal system included rights violations, slowly disintegrating physical structures, and highhanded measures coupled with coldness in addressing matters pertaining to the welfare of convicts and other detainees. This article demonstrates that the seemingly contemporary penal problems The Gambia is grappling with are colonial legacies. Also, it makes evident why the country needs a home breed solution which is not necessarily prison reforms per se, in addressing the problem, rather than imitating European perceptions, most of which do not fit the Gambian setting. It equally accentuates the need to justify calls for a holistic transformation, rather than a simplistic reformation of the penal system. The essence is to fashion a solution that could also address other cases in point of institutional decay which pervades most of the colonial leftovers in the country

After independence in 1965, as a continuum of the colonial dispensation, the prisons remained incarceratory sites for incapacitating those opposed to the post-colonial order while the therapeutic effects European reformation efforts had on European societies were cast overboard to glorify the colonial agenda to which the post-colonial government embodies. Marxist scholars are of the opinion that penal institutions were tools for enforcing oppression, and for sustaining the political and economic interests of the ruling class. ${ }^{5}$ Hence, both the post-colonial governments and their predecessor used the penal system to legitimise and venerate colonialism.

Different forms of punishments were meted on pre-colonial Gambia offenders. These were uncodified laws which mandated criminals to compensate their victims to restore the latter's status to position. ${ }^{6}$ Contrasting the colonial practice where compensations in the form of fines are paid directly to the state, and offences were treated as wrongs against the Queen of England, offenders in pre-colonial Gambia in most cases compensates victims or their family members, as situation demands. ${ }^{7}$ This made crime to be treated as a breach of communal relationship. ${ }^{8}$ Others include, depending on the gravity of the offence, tendering apology, community service, shouldering responsibilities for bodily injuries in case of assault, footing burial expenses in murder cases etc. Additionally, banishment from the community, if the offender's presence threatens communal existence was in vogue. The principle of collective responsibility permitted family members to

4 Abiodun Tosin Fumi. A historical study on penal confinement and institutional life in southern Nigeria, 1860-1956. Ph.D. dissertation, University of Texas at Austin, (2013), 2.

$5 \quad$ Ibid 4,9

6 Ibid 4, 47

$7 \quad$ Ibid 4

8 Ibid 4, 44 
bear part of an offender's expenses in diverse ways. Somehow, the pre-colonial Gambian approach to crime and punishment and that introduced by European reformists dovetailed: crime will never be healed nor law breaking controlled by all the prison a society can build, as long as society shuts its eyes to the causes that make laws, penalties, and prison institutions indispensable. ${ }^{9}$ The causes of crime exist outside prison yards, therefore the problem should appropriately be addressed outside the prison perimeter hence the real remedies should be applied on the outside, not inside. ${ }^{10}$

With respect to the fact that societal mind and ethical standard are a summation of those of its population, ${ }^{11}$ the conducted Mile 2 prison tour engendered a national outcry cutting across political divide, for urgent prison reforms. ${ }^{12}$ The problem of crime will remain cancerous if the institutions society entrusts with the responsibility to control it proves incompetent in repressing and correcting the aberrant tendencies of lawbreakers. ${ }^{13}$ However, as long as mile 2 is securely shut out of public view, what happens behind its walls will remain a secret. ${ }^{14}$ Fierce criticism besieged what lay behind the walls of Mile 2 and other detention sites and lockups across the country, coupled with the attendant despicable conditions prison inmates have been subjected to, which for two centuries, they kept classified after regaining freedom. Had the world behind the walls of Mile 2 been long exposed, the shock it engendered would not have caused so much desolation let alone clarion cries in society.

There are three purposes of institutional confinement in modern societies. ${ }^{15}$ Retributive punishment is a measure used by the state to guard the values and conventions on which social life is based. The reform school of thought concerns how societies confine criminals in prison to reform and turn them into respectable citizens on the one hand, and in order to prevent further offences through the strategy of rehabilitation on the other hand. The third criminological school of thought concerns deterrence which addresses relationship between punishment and criminal behaviour at individual and group level. Societies discourages crime by sending offenders to prison or punishing them by other means. By punishing criminals, potential criminals are deterred. Hence Prison is meant for prisoners, convicts undergoing state sanctioned punishments imposed by the courts. ${ }^{16}$

Most societies endeavour to strike a balance between punishment, reform and deterrence. However, in colonial Gambia, there were ulterior motives at play as prisons were designed to

9 Byers P. Joseph. "Prison Reform," Journal Of Criminal Law and Criminology (872), (May 1915 to March 1916), 873 .

$10 \quad$ Ibid 2, 873

11 Robert Ringer. The Individual Versus the State. (2017) https://robertringer.com/individual-versus-state/

12 https://info.undp.org/docs/pdc/Documents/GMB/Prison\%20Photobook.pdf

13 Charles, A. Ellwood, "English Prison System and What We Can Learn from It," Journal of American Institute of Criminal Law and Criminology, (May 1916 to March 1917), 22

14 Vincent, M. "Have the courts made a difference in the quality of prison conditions?" Pace Law Review, (2004) 419; Michael B. Mushlin "I Am Opposed to This Procedure: How Kafka's In the Penal Colony Illuminates the Current Debate About Solitary Confinement and Oversight of American Prisons," 93 Oregon Law Review. (2015). 571

15 Ibid 4, 6.

16 Zahid Anwar S. and Zubair Shah (2016) "A History of Prison Reforms in Pakistan." Global Regional Review, 1 (1). 
control those deemed to be recalcitrant members of society, which includes criminals and dissenters to foreign domination. This class seem to pose a threat to the security of the scanty European population in the colony.

This article which is an input to West African prison literature shows that the colonial prisons of The Gambia differed from those in Britain in the latter part of nineteenth to mid twentieth century. It takes a cursory look at the neglect of the physical facilities that housed convicts and those awaiting trials. The convicts were, so they say, undergoing reforms in colonial Gambia prisons, structures and systems which the post-colonial political dispensation inherited and preserved with dedication. Members of the public were alarmed on catching a glimpse, on television, of the world enclosed by the prison walls, despite not having an inkling of other multifaceted aspects of the dilapidated Mile 2 prison facility, especially the social life behind the 'iron curtain.' On this account, the article examines the physical structures on ground, dating back to the nineteenth century when prison was introduced in The Gambian, to gauge the level of desolation the penal infrastructures have been subjected to ever since. In addition, it suggests a plausible solution to the problems posed by the archaic structures, and what should be done to get rid of them. These goals are addressed with the notion that wholesale importation of mechanisms for guarding prisoners' rights, from one country to another, is an exercise in futility. That is where the British colonial, and indeed the post-colonial African authorities slipped. ${ }^{17}$

\section{Methods}

Records of official interactions among colonial administrators, now in the repository of the Gambia National Archives are the principal sources of information. These include correspondences of colonial governors and their secretaries, travelling commissioners (TC), as well as other government functionaries in their course of managing the affairs of the colony. Other sources include publications on different aspects of the theme, peer reviewed articles and internet sources. Population projection was calculated based on the method in use by The Gambia Bureau of Statistics ${ }^{18}$ while population census figures were compiled from publications of the same

\footnotetext{
17 Anne, Owens "Prison inspection and protection of prisoners right," 30 Pace Law Review (2010) 1535,

18 Note: population projection was based on the method in use by The Gambia Bureau of Statistics.

$\mathrm{Pn}=\mathrm{P} 0[1+\mathrm{r}] \mathrm{t}$

$\mathrm{Pn} / \mathrm{P} 0=[1+\mathrm{r}] \mathrm{t}$.

$[\mathrm{Pn} / \mathrm{P} 0] 1 / \mathrm{t}=[1+\mathrm{r}]$

$[\mathrm{Pn} / \mathrm{P} 0] 1 / \mathrm{t}-1=\mathrm{r}$

$\mathrm{Pn}=$ Present Population.

$\mathrm{P} 0=$ Population of Base year.

$r=$ Growth Rate (population growth rate in use by the Department of Statistics is 2.8 percent.)

$\mathrm{t}=$ Time.
} 
establishment. Information on the annual prison inmates admitted to three prison facilities were collated from official annual reports on the colony. ${ }^{19}$ Being a monocrop agricultural colony, from colonial archival files on the colonial West African Currency Board, available data on groundnut exports and the corresponding market prices from 1912 to 1948 (part of the second half of colonial rule), was compiled. Jarrett H.R made figures on monetary allocations from the West African Currency Board to the colony handy. ${ }^{20}$ The juxtaposition of these materials add credence to the recommendation to have the entire prison system phased out.

\section{Discussion $^{21}$}

Andrew Coyle who examined how imprisonment is used in different cultural settings subsequently classified prisons of the world into five categories. The first constitute countries with no indigenous ideas of prison like most sub-Saharan cultures. The second group consists of violent prisons like those in most Latin American states. The overcrowded prisons was next, like those in the former Soviet Union, Central Asia and Eastern Europe. Another was where prisons are regarded as a place of last resort, where the irredeemable and those who committed heinous crimes are sent for reformation. Most Western countries with an incarceration rate of 30 to 100 per 100,000 falls within this category. Lastly, there is a class of prisons in countries that adores prisons, the most notable being the United States with over 2,000,000 people in detention. The average rate of imprisonment in the States is 700 per 100,000 while that of the world is 40 per $100,000 .{ }^{22}$ This section of the article is in three parts. The first explains the colonial prison condition, followed by a 1957 report compiled by the colonial director of medical services which addressed the state of affairs at the central prison officers' quarters. Lastly, a subsection analysed the situation of the colony as far as prison condition is concerned.

\section{(1.1) Prison Condition in Colonial Gambia}

Similar to other non-centralised pre-colonial West African states, The Gambia had neither the culture nor home-grown knowledge of incarcerating criminals in places branded as prisons, partly due to the high capital outlay and other operational costs associated with running such facilities. ${ }^{23}$ This placed her in category one of Andrew Coyle's classification. Besides, the underlying European penal philosophy of managing prisoners contravene Gambian customary values that places higher

The base year is 2003 the last census. (Omasanjuwa, A. and Phebean, J. 2013).

19 Appendix 2[b].

20 Jarrett, H.R. “The Strangers-Farmers of The Gambia.” Geographical Review, 39 (4), (1949) 53

21 In modern parlance, penal systems are known as correctional services. However, this article retained the old nomenclature for two reasons. Firstly, that was the term in use throughout the colonial era. Secondly, viewed against the background of what obtained in nineteenth century Britain and modern trends, the Gambian penal system is in no perceptible way correctional.

22 Andrew, Coyle "Prison Reform Efforts around The World: The Role Of Prison Administrators", 24 Pace Law Review, 825. (2004).

23 Ibid 4, 43-64 
premium on reconciliation and social cohesion among contending parties, rather than retribution. ${ }^{24}$ Even in the centralised pre-colonial West African states that maintained facilities comparable to prisons, similitude of prisons neither rehabilitate criminals nor enforced standardised sentences in the European sense. They were merely holding facilities harbouring suspected offenders awaiting trial. $^{25}$ These features sets pre-colonial Gambian approach to justice apart from the penal theories propping European penological goals. This subsection explains how the introduction of European prisons, part of the colonial ideology of assimilating Africans to European customs and practices, was fraught with incongruities that plagued the penal institutions in the colony.

The Gambia Annual Reports of the Prison Department (1927-1935) listed the offences for which persons were convicted and commuted to prison as murder, manslaughter, indecent assault, rape, and wounding. Others include housebreaking, false pretences, stealing, stowaway, and possession of dangerous drugs. ${ }^{26}$ However, the list omitted data on a class of prisoners and detainees which in modern parlance are referred to as political prisoners as there was no such appellation in colonial Gambian statute books, hence they were treated as criminals and, in some cases, off record. Also, virtually throughout the colonial era, detainees awaiting trial were lumped together with convicts, an indication of the ineptitude of the prison system.

The steady disintegration of the Gambian traditional system, subsequent to the advent of Europeans who introduced a foreign legal system and the ensued foreign rule, contributed to the causes of crime in the country and indeed in British West Africa. The introduction of the British legal system in West Africa redefined and reclassify crimes and changes in its social perception in society ${ }^{27}$ hence, the steady increase in the number of incarcerated persons. Apart from the seasonal itinerant labour demands on groundnut farms, the commercial firms and government building operations, the colony lacked industries and other sources of employment. The seasonal farming of groundnuts does not really offer all year round employment that can rehabilitate ex-convicts. What prevailed in the Nigerian prison system replicated The Gambia situation during the period: young, poorly educated and economically disadvantaged group constituted the majority of the inmate population. ${ }^{28}$ In the neighbouring French controlled colonial Senegal as well, prisons did not to meet the standards of those in France. ${ }^{29}$ On this account, the article identified unemployment in the colony as an important factor which fuelled the steady increase in number of offenders that were incarcerated in prisons and other holding facilities throughout the colony.

26 Colonial Gambia Annual Reports. The Gambia Prisons Department 1927-1935. Gambia National Archives, Banjul, The Gambia.

27 Paul Osifodunrin, Property Crime in Nineteenth Century Lagos: Criminal Tradition or Popular Culture of Accumulating Wealth, unpublished paper, (2010): p. 33. Cited in Abiodu Tosin Fumi A historical study on penal confinement and institutional life in southern Nigeria, 1860-1956, 92. (2013).

28 Etannibi Alemika "Socio-economic and Criminological Attributes of Convicts in Two Nigerian Prisons," Journal of Criminal Justice 16 (19). (1988).

29 Dior Konate, A History of the Penal State in Senegal: Repressive Architectures and the Life of Prison Detainees from the 19th Century to the Present, (Ph. D diss., University of Wisconsin.) (2006) 123 
Before 1853, the top floor of the first prison, located at McCarthy Square, consisted of individual cells while the ground floor housed the association cells which were expanded to accommodate from 20 to 38 inmates and in $1848,36 .{ }^{30}$ The prison which was opened in 1821 comprised of a building which was virtually indistinguishable from others in its neighbourhood and hardly shaped by the demand of modern penology. ${ }^{31}$ During that era, in Britain, the penal reform movement anchored on the separation of prisoners' cells was well under way, but not in colonial Gambia. Gambian prisoners, for instance were not classified by their offences, save debtors who were confined on the second floor in individual cells, different from the association wards on the ground floor. The Annual Colonial Report of 1891 highlighted that among the twelve ordinances passed that year was one abolishing the visiting justices of the prison and the appointment of the inspector of prisons, apparently to underscore the importance of the prison. ${ }^{32}$ Some improvements in the management of the prison were introduced when a change was made in the gaoler and other officers. In December 1891, an officer Mr. Western, of the Imperial Convict Service arrived the country to educate native warders in their duties. During his visit, a proposal was floated to enlarge the prison and upgrade the internal arrangements. When works were finished, it was estimated that the gaol will be second to none in colonial West Africa.

Undisputedly, overcrowding led to disease outbreak which spread chillingly, rather than discipline and correction. As dignified living conditions cannot be attained in an overcrowded environment, death rate among prisoners escalated overtime. ${ }^{33}$ Yet, official annual reports on the state of the colony consistently rated the health of prisoners as being in top form, despite that there was hardly any annual report that did not contain information on death of prisoners. In 1853,160 of the 298 fell ill at various times while in 1868 the number increased due to outbreak of cholera. In 1846, six deaths were recorded, two and nine deaths occurred per year from 18471870. These official numbers, though may be trivial, points to the corrupt nature of the prison. ${ }^{34}$ In 1880 it was discovered that substantial beef and rice meant for prisoners were embezzled by Mr. Travers, the gaoler, along with other co-conspirators who resold the food on the market. ${ }^{35}$ Later in 1901, it was contemplated to erect a new prison but it appeared that work could not begin then due to cost implication. ${ }^{36}$ In 1903, the prison was renovated and the cells were enlarged to ease accommodation problem, but the "separate system" was not introduced due to lack of space. During day hours prisoners were engaged in groups while at night they retire to different cells with three to four sharing a ward..$^{37}$

$30 \quad$ Ibid 2,55

$31 \quad$ Ibid 2, 55

32 Gambia Colonial Annual Reports 1891. https://libsysdigi.library.illinois.edu/ilharvest/Africana/Boo ks2011-05/466568/466568_1890/466568_1890_opt.pdf

33 Cindy, S. Woods "Addressing Prison Overcrowding In Latin America: A Comparative Analysis of The Necessary Precursors To Reform.” Journal of International Criminal and Comparative Law. (2016) 22,

34 Ibid 2, 3

35 Etannibi Alemika "Socio-economic and Criminological Attributes of Convicts in Two Nigerian Prisons," Journal of Criminal Justice 16, (1988) 63

36 Annual Gambia Colonial Reports for 1901.

37 Archer Francis Bisset Archer, "The Gambia Colony and Protectorate: An Official Handbook." Frank Cass \& C. Ltd., (1967) 135. 
Rather than upgrading sanitary conditions, the increase in the number of inmates outpaced the expansion of the prison facilities, without reforms. The floor of the Bathurst cells was at the un-cemented ground level. The governor recommended that if the health of the prisoners is not to suffer, the floors should be raised at least six inches, if not one foot, and the floors should be cemented to prevent moisture from getting into the cells and to enable the cells to be kept cleaner. In addition, the walls of the cells should be faced with cement. ${ }^{38}$

Apparently to address the problem of congestion, by an ordinance of 1933 as amended by that of number 3 of 1935, the Governor officially approved prison sites at Georgetown, Kerewan and Basse as native prisons for inmates not serving more than three months sentence. A store subsequently built on the order of the North Bank Province Acting Commissioner in May 1935 was used as an office as well as Kerewan Prison. Pertaining to Kerewan Prison, the Colonial Secretary (C S) was informed by the Commissioner, North Bank Province that the building had the following defects: fencing, grass roofing, the menace of white ants eating up the roof, among others. He therefore offered a plan of a prison yard for replacement. The plan include cells, a mud wall covered with broken bottles at the top as the use of barbed wire will be expensive. However, grass roofing was unsatisfactory as it leaks and fairly easily blown off and has to be renewed frequently. About one hundred sheets of corrugated iron sheets would suffice. In 1938, a new hospital was opened in Bansang which enabled part of the health facility at Georgetown to be converted to prison. ${ }^{39}$

The TC in 1935 informed the C S of a directive issued for the replacement of the mud thatched round building with a suitable rectangular building, with a proper door and locks with corrugated roof. The building, Basse prison, was only a hut which was most unsuitable for the purpose. The prison facility was not supplied with boards or blankets, though no prisoners stayed longer than a fortnight there before being moved to other detention sites. On December 9, 1935 the T C reiterated his earlier plea to the C S that Basse Prison consisted of one hut with mud walls and a grass roof which would be easy for a prisoner to escape from. There was no wall in enclosure or barbed wire fence. Only a krinting fence which is little or no obstacle to man or beast. He proposed the building of a new prison without delay. ${ }^{40}$

In the opinion of the Inspector of Prisons on September 16, 1935, neither the building at Georgetown or Basse complied with Home Office requirements relating to cubic feet of space per prisoner hence he recommended improvements being that a person of Asiatic decent could be incarcerated there. All the commissioners, he emphasised, wanted trained warders. On his return to Bathurst, the TC requested the Public Works Department to put up a plan and estimate for a prison at Georgetown and Basse. Attached to the report was the plan for the proposed buildings which he strongly recommend the Governor to approve as they complied with Home Office requirements pertaining to space and the question of white ants eating up the wood will be eliminated. ${ }^{41}$

38 Native Prisons- Protectorate. Gambia National Archives File No. 2/1533

39 Annual Gambia Colonial Reports for 1925.

40 Dior Konate, A History of the Penal State in Senegal: Repressive Architectures and the Life of Prison Detainees from the 19th Century to the Present. (2006)

$41 \quad$ Ibid 38 


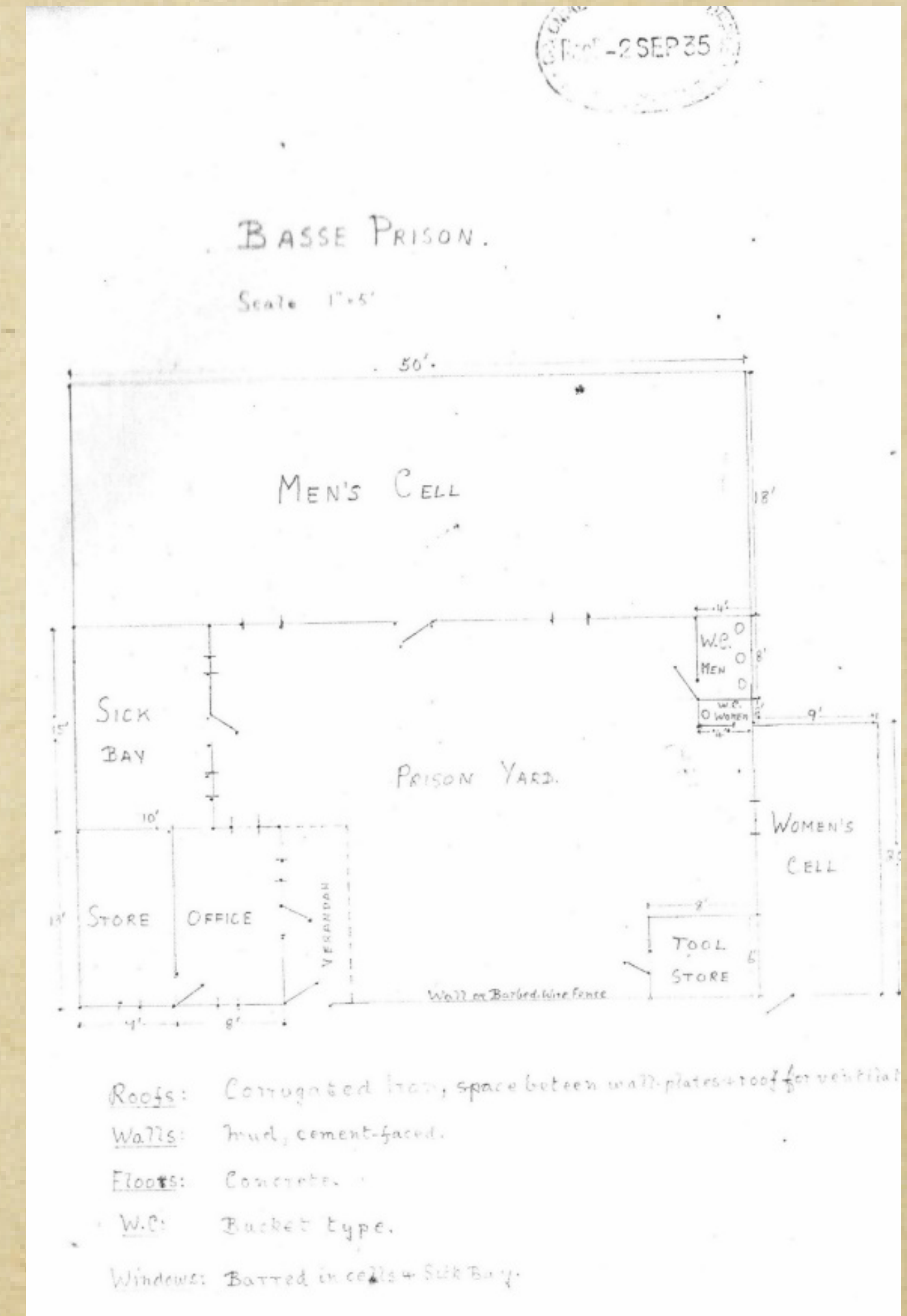

Figure 1 Colonial Basse Prison Plan---Courtesy, Gambia National Archives, Banjul, The Gambia. 
The Commissioner of the North Bank Province felt that some provisions should be made for prisoner's accommodation as two of whom he saw at the Basse facility were practically nude and others were doubtlessly in the same plight. Similar situation, going by the Commissioner of North Bank Province report of 1941, was prevalent at Kerewan Prison where mosquito gauze were not affixed to the eaves of sleeping quarters and there was no separate female prisoners quarters. ${ }^{42}$

On November 12, 1935, the T C had cause to alert the C S that when Basse was approved as a native prison, in the handing over note it was stated that the prison will be administered in line with prison regulations in all aspects. He explained that that hot been the case as it is impossible to administer the facility in line with stipulated regulations until another is built of suitable construction to comply with existing prison regulation. He submitted that he had no house to put the furniture they had as the house is not in order. The prison plan submitted by the Acting Commissioner Upper River Province does not altogether comply with prison regulations nor that relating to medical officer and chaplain he added. There was neither a matron nor a gatekeeper. He recommended that new native prison regulations be drawn up to conform with conditions appertaining to the protectorate. On December 13, 1935 a copy telegram dispatched to the police in Bathurst advised the organisation to decline responsibility as regards prisoners unless it can supply the necessary warders to look after them as two warders cannot look after prison and comply with prison regulation. There are twelve prisoners and one awaiting trial and the prison has no enclosure for exercise and only one hut for lockup. ${ }^{43}$

The T C of Upper River Province on January 15, 1936, informed the C S of the Governor's order to shut down the Native Prison at Basse and all persons sentenced in the Upper River Province to prison terms not exceeding three months to be sent to the Native prison in Georgetown while warders with prison equipment were posted to Georgetown. Accordingly, fifteen convicted prisoners were transferred. The order was executed with the understanding that the Basse Native Prison will revert to a lockup where prison regulations will no longer apply and the prisoners of fourteen days sentence will be kept. Permission was sought to hire a paid native messenger to look after detainees awaiting trials and others to be transported to other detention facilities. As a follow up, prisoners form the South Bank Province serving sentences not exceeding three months were to be accommodated, when possible at Kerewan. However, prisoners could first be sent to Bathurst before being relocated to Kerewan. ${ }^{44}$

At Georgetown prison, going by the report of the inspector of prisons on February 25, 1936, warders were living in huts scattered about the town instead of close to the prison, and the prison itself was open to public view. The inspector strongly recommended the building of huts for warders and a krinting fence be erected around the prison, not for safety but to protect the prison building from curious view of passer-by. The work could be accomplished for about $£ 30$. As the prison was built on the side of the main road, it is therefore necessary that it be enclosed in a fence of $51 \mathrm{x}$ 160 feet. In the same report, pertaining to Kerewan prison, the inspector was dissatisfied with the layout. The office, bathroom and latrine for prisoners were too far from the prison itself. Warders

$42 \quad$ Ibid 38

43 Annual Gambia Colonial Reports for 1901.

44 Annual Gambia Colonial Reports for 1901. 
didn't have latrine nor washhouse. He therefore attached a plan of a proposed prison in replacement of the existing facility because the prison building was not safe in a condition when the grass roof was often sodden with rain.

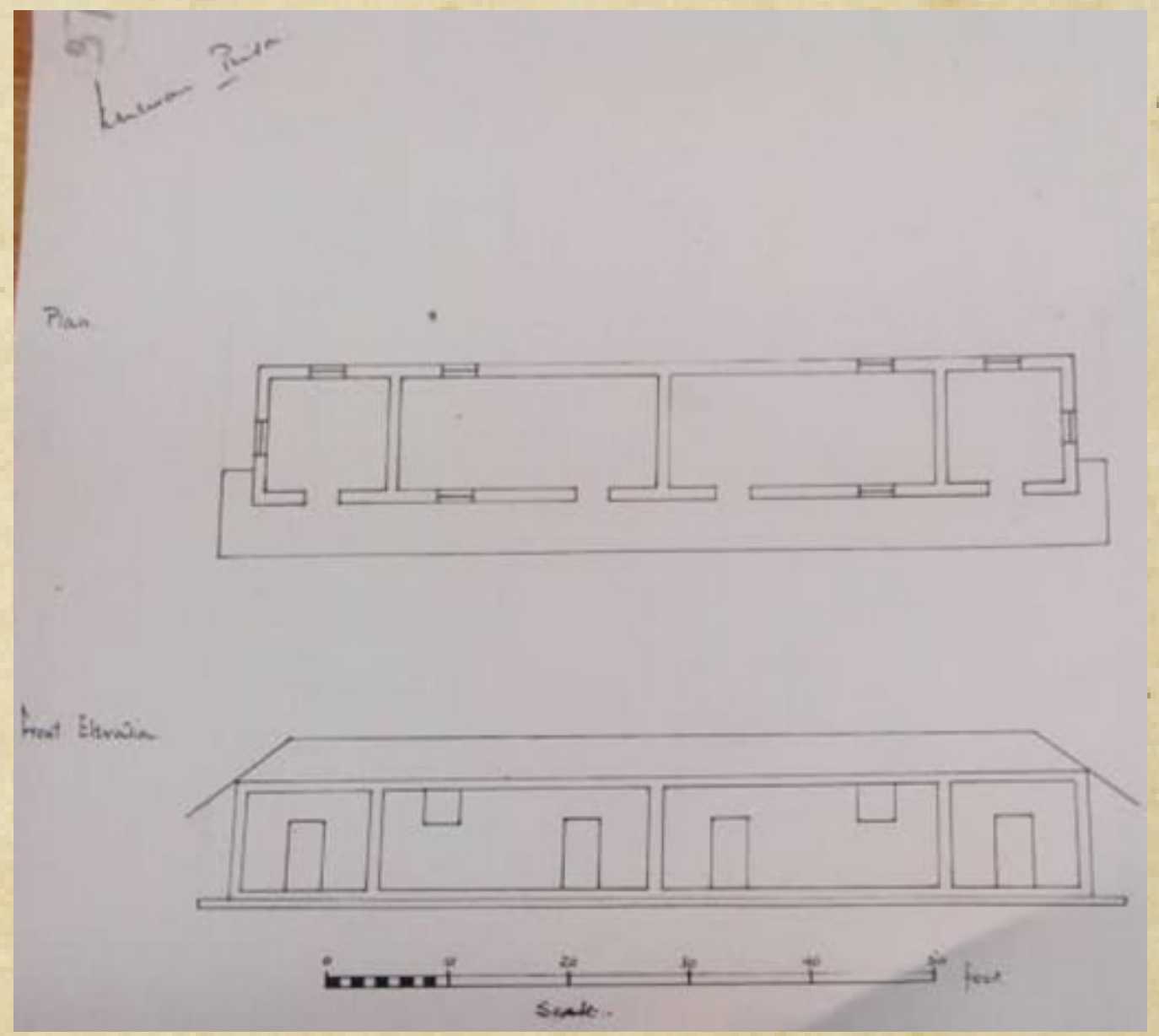

Figure 2 Proposed Colonial Kerewan Prison Building Plan. Courtesy of Gambia National Archive, Banjul, The Gambia.

In one cell, the ceiling was propped upwards to the danger of falling. The thatched roof had been eaten by white ants hence it could not stand another rainy season, the Commissioner of Police in Bathurst was also notified.

The Commissioner of McCarthy Island Province informed the Inspector of Prisons on April 2,1936 of the only two warders' huts in the prison premises but neither could be used as they had no doors or windows besides, there was no duty during the day. The Commissioner stated that he need not emphasise the necessity for warders to live near the prison and not scattered about in town in private compounds as they were compelled to do. It will cost only $£ 5$ to have the doors and windows made and fitted. However, request to spend $£ 5$ on the doors and windows was initially declined but the governor had to sign a special warrant for the release of the fund for the repairs. ${ }^{45}$ 
On May 11, 1936, the TC of the North Bank Province suggested the demolition of the entire prison hut at Kerewan, to the $\mathrm{C} \mathrm{S}$. He recommended that the prison be put in proper shape at the cost of $£ 65.0 .0$ with 150 yards of barbed wire. Subsequently, the T C wrote the C S on December 1,1936 notifying him of the completion of the prison. He sought permission to transfer prisoners from the province serving time at Mile 2 back to Kerewan, and also to post complement wardens. The senior medical officer equally approved the suggestions.

Complaints from the North Bank Province T C on December 6, 1936 reached the C S pertaining to the need to fence Kerewan Prison premises. The initial two reels of barbed wire approved for the project proved insufficient hence more reels were purchased for $£$ 7-18-08 for the Provincial Emergency Development fund. The Inspector of Prisons approved the reopening of the Kerewan Prison on January 25, 1937 after $£ 9$ was spent over and above the $£ 65$ originally approved for the fencing. Subsequently, on February 2, 1937, the Governor, in compliance with Native Tribunal Ordinance of 1933 declared Kerewan prison North bank Province as a Native Prison for the purpose of the ordinance. In line with section 259 of the criminal procedure code permission was granted to imprison persons sentenced by both provincial and native courts. ${ }^{46}$

The North Bank Province Commissioner in a dispatch informed the Inspector of Prisons, on February 8, 1938, about the only two prisoners at the Kerewan facility serving time and they were to complete serving within one month, hence there is the possibility of closing down the prison. Despite that it was agreed in 1937 that South Bank Province would supply prisoners to Kerewan, none had been received from that province. He suggested that prisoners serving up to six months in Georgetown could be sent to Kerewan, not Bathurst, as Georgetown prison was to be moved to the hospital premises within six to eight month time. ${ }^{47}$

By the year 1940, due to the WW II economic measures in force, and to reduce the dispersal of warder and staff coupled with problems of supervision, talks were abound concerning the closure of the Kerewan prison facility.

\section{(1.2) Director of Medical Services 1957 Report on Mile II Prison Officers Quarters.}

Meanwhile, the ramshackle condition of native prisons at Kerewan, Basse and Georgetown was not peculiar to that section to the colony (known as protectorate) as the situation was in no perceptible way different from what obtained at Mile 2, the central prison. On August 10, 1957, less than a decade to the cessation of colonial rule, the director of medical services submitted a report to the CS on prison officer's quarters at Mile 2, highlighting the derelict state of the facility. ${ }^{48}$ The report lamented the nature of the old though well-kept prison. Plans were afoot to erect a new prison building on an early date which will harmonise with modern principles. Sixty-three years later, nothing has changed, no new prison has been built. 


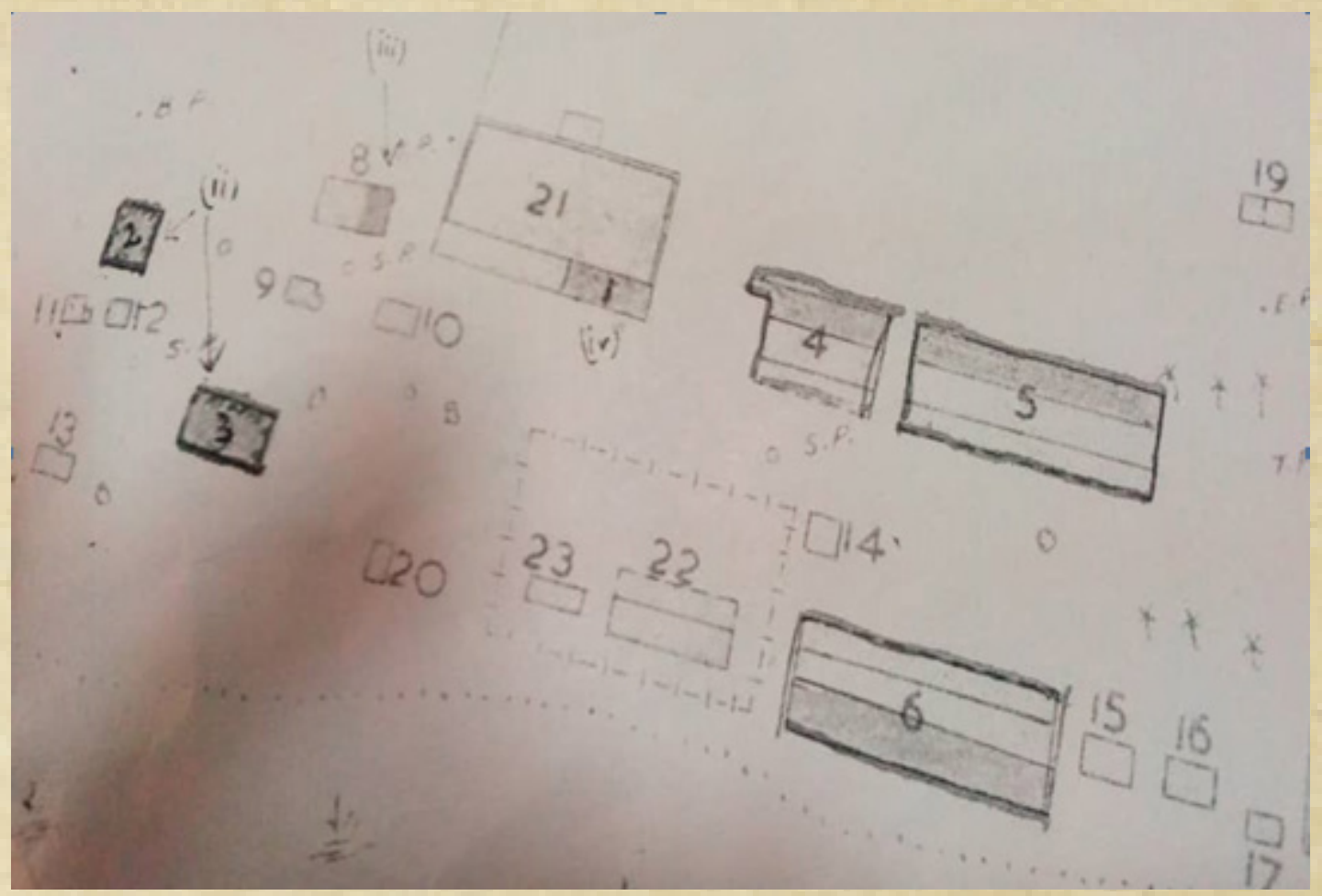

Figure 3. A sketch diagram of Mile Two prison during the colonial era."

In the year 1900, the only prison in the colony was that at McCarthy Square, with a capacity for 31 males and 7 females, built in 1821. The facility was moved in 1920 to somewhere along Cape St. Mary Road, (now Mile 2, initially built as a sanitary isolation station). Further development followed in 1921; some buildings were erected which enabled the facility to hold 130 men while additional expansions were under consideration. ${ }^{49}$ In 1924, a female wing and quarters for the matron were added, and no further changes were made except the association wards that was fitted with wooden bed concrete support to enhance easy scrubbing of the board, that was in $1925 .{ }^{50}$ Still, the prison was not on the separate system as there were four associated wards for male prisoners and two for female. The condition persisted as of April 20, 1934 when the prison annual report was compiled. Classification of prisoners as known in the prisons of the United Kingdom, the report contained, is a different problem on account of architectural design hence classifications are kept separate as far as accommodation permits. ${ }^{51}$

As of 1931, the only prison was still that at McCarthy Square hence, in 1930 the average number of those in confinement per day was 56.15, in 1931 it was 77.50; an increase of 21.35. The increase was due to the prison at Georgetown being shut down on June 10,1930 and all 18 prisoners were relocated to Bathurst. Meanwhile, there was no increase in manpower to cope with extra work. The new facility was designed to hold 150 prisoners in its 3 association wards and 5 solitary confinement cells. Also included was an infirmary, a cook house, stores and out houses.

49 In 1925, the former prison yard was converted to a power generating station. One of the $100 \mathrm{kw}$ engines was supplied by Rsuton Hornsby and Company at the end of the year. Gambia Annual Report. 1923.

50 Gambia Annual Colonial Report of 1925.

51 Gambia Annual Colonial Report of 1934 
Accommodation was provided for the warders close to the prison yard. The staff consists of the Inspector of prison, (who was the Commissioner of Police), an African Chief Warder, and 19 other African Warders. As very few females were imprisoned, separate accommodation was provided them in the charge of a matron. All prison sentences exceeding 14 days must be served in Bathurst Prison as of 1932.

Rooms in the quarters were undersized except the four poorly ventilated rear rooms. Windows consisted of wooden shutters and the rooms were consequently very dark. The rear rooms were of insufficient height, being only eight feet three inches above the ground. Extensive cracking, of the rear walls of the erected 1951-1952 rear rooms, was taking place. The rear walls of the row quarters near the Lagoon, was down to high tide level. The roofs of all the quarters were leaking, and some to such an extent, that families refuse to occupy same, and preferred rented accommodation in the town, at their own expense. For that reason, ten quarters were empty. Roofing and ceiling were defective, and required complete re-roofing. The veranda floors required repairs in many places and reroofing. The average room per officer was two, and each officer averages three children along with his wife. Some of the walls of the old quarters were also cracking badly.

The two rooms of the remand house were allocated to an officer with family of a wife and three children aged 11,8, and 4 years. Each room was badly ventilated, and insufficiently lighted. On account of this, the officer abandoned these quarters, and shared a two-room house with a fellow officer. There was no cross ventilation, which made it poor for human habitation. A room adjoining the Club House was not completely separated by the partition wall, there being an area of approximately 4 feet, between top of partition wall and roofing, and the Club House by means of the door. This, the report stated, was most unsuitable for human inhabitation. It was most undesirable from a health point of view to have a person's rest interrupted by club activities. The roofs of two detached building were leaking, while the krinting and plaster walls were in need of repairs. One of the rooms was ill-ventilated. Also, the roof of the female quarters was leaking with the living room ill ventilated.

The director recommended two alternatives, either (a) a complete rebuilding of new quarters or (b) repair of existing quarters remedying the above stated defects, and in the case of the three blocks of quarters conversion of two single quarters to make one double quarter, and substitution of glass windows for wooden windows. In view of the forgoing remarks, it was recommend that consideration be given to rebuilding these quarters.

Only five latrine pails, which includes a private one, adjoining on to one of the quarters were available for 93 persons, including wives and children who should normally live in the compound. This was insufficient, and it was suggested that water closets should be provided to replace the latrine pails, and water cisterns should be made available in the ratio of one for every two families. There were five bathroom, one of which was a private, and it was suggested these be provided in the same ratio as water closets.

Leading from the prison and two bathrooms, were drains in need of urgent cleansing, as water was stagnant and likely to cause mosquito breeding. As for water supply from four standpipes, one required a new concrete surround drain it to the lagoon. Also, the four kitchen walls required repairs. Refuse was thrown indiscriminately in the surrounding quarters and was undoubtedly the cause of fly complaints. This area required immediate cleansing hence dust bins were procured for 
storage of refuse, and daily collection of same by Bathurst Town Council.

\section{Analysis}

The chronology of the dilapidated prison architectural structures of The Gambia has been the focus of this article. Fundamentally, there was no need for the shoestring economic measures British administrators adopted while running the colony, the bane of the penal system. In the years 1930-1934, The Gambia was sixth among groundnut-exporting countries, supplying 3.62 percent of world production. ${ }^{52}$ Appendix 1(a) shows the total volume of groundnuts produced in the colony which Britain had the monopoly of fixing the sales prices, all of which she purchased. 1 (b) displays the monetary allocations to the colony from the West African Currency Board where the foreign earnings are managed in reserve by the colonial administrators. The shortfall is a clear indication that British colonial rule short-changed the colony as her development needs was of subsidiary priority. One standard prison yard would have suffice to cater for a population of about 315,484 at independence. ${ }^{53}$ The post-colonial governments equally fared badly. With a population of less than three million, and among the lowest per capita rate of incarceration 31 per 100,000 (691 prisoners including $66.7 \%$ foreigners) more needs to be done.

For multifaceted reasons viewed against penological principles, it is evident that both the colonial and post-colonial administrations performed below expectation in running the penal institutions. While enforcing the retributive goal of protecting societal values and conventions, recidivism rate was ignored at public expense. The criminological and reformative schools of thought were cast overboard in the scheme of things. Similar to its successor, the colonial administration invested next to nothing on the facilities partly because it operated within an administrative straightjacket micromanaged from the Colonial Office in London. From the look of things, there was too little or no room for local conditions to be factored into policy implementation, packages doled out from London. It is for this reason that those on the frontier line paid lip service to a number of issues, including prison conditions. An explanation for the uniform penal conditions throughout British West Africa. ${ }^{54}$

None of Gambia's penal institutions bore an iota of semblance to any in Britain in terms of architectural design and classification system. Gambian prisons were all a mismatch to the edifice that housed Pentonville prison which in 1842 was the standard prison in Britain and her colonies, emulated in India, Canada, Burma, Malta, and Australia. ${ }^{55}$

British colonial administrators introduced the justice system to enhance domination rather than protect the rights of colonial subjects. This was validated in colonial and post-colonial Gambia. ${ }^{56}$ However, from the viewpoint of the former, the introduction of prisons reformed the indigenous solutions to the problem of crime and criminality in society. In colonial Sierra Leone for example, members of The Human Leopard Society were the prime suspects in murder cases hence concerned

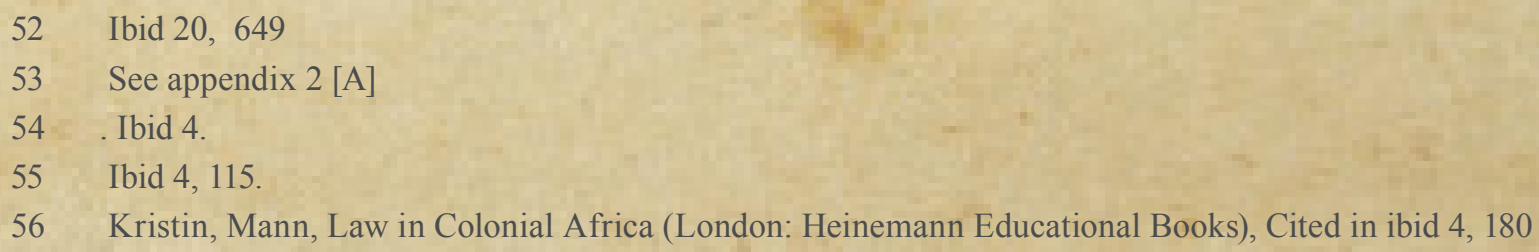


members of society, including chiefs, endeavoured to get it exterminated. During an inquiry led by Sir D.P. Chamlers into an 1897 uprising, it was discovered that in 1880-1881 almost 200 people were burnt for their membership. ${ }^{57}$ However, the colonial authority that could not view the justice system with coldness declared it illegal. Consequently, towards the end of 1894-1895, there was a murder bonanza for members of the society. In reaction to the endemic cries, and the urgent need for an alternative justice system, The Human Leopards Ordinance of 1895 came into effect, making its membership and other allied organisations penal. ${ }^{58}$

The Colonial Office in London secured the services of the former Chief Justice of Gold Coast, Sir William Bradford Griffith, to preside over a special commission court to try murder cases. Sir Griffith was of the opinion that education and religion should supplant the crude native beliefs. On the face value, the suggestion seems plausible. However, among those convicted and subsequently publicly hanged for murder, were educated Christian clerks, traders, headmen, and chiefs of the towns as well as catechist and missionaries. A case in point was that of a well-read Christian missionary of The United Brethren in Christ Church, born in the United States. It was difficult to conceive how a man of his stamp could be connected with a cannibal society, besides, he had allowed himself to be elected a paramount chief of one of the chiefdoms of the protectorate. ${ }^{59}$

It is noteworthy that the penalty prescribed by the traditional justice system and the special court dovetailed: Public execution.

The bane of the Gambian quagmire was also rooted in the absence of nigh on any penal philosophical theory in addressing the welfare of prisoners and detainees in the colony. Even in the judicial sector, there were glaring defects, particularly during the early phase of colonial rule. The setting up of an independent judiciary increased the number of cases, but misdemeanours were rampant and offenders were often tried outside of court by magistrates with virtually no legal training. Magistrates rarely demanded evidence beyond the word of dependable witnesses to secure sentences. ${ }^{60}$ Between 1840 and 1849 , the vast majority of cases tried were not in courts, but before a magistrate who passed sentences without trial. ${ }^{61}$

There were three prison yards in the country in 1954. The Central Prison at Mile 2 handled all categories of prisoners while Jeshwang Prison 7 miles from Bathurst, opened in 1952, admitted first and second offenders which permitted separation of Europeans from Africans; and Georgetown Prison which was about 180 miles from Bathurst was under the supervision of the Divisional Commissioner. In 1954, 34 years after Bathurst prison yard was relocated to Mile 2, the foremost infrastructural improvements was the construction of a new kitchen and re-building of three associated cells which were originally of krinting walls with cement blocks though there was general renovation of all buildings at Jeshwang prison. The surrounding walls of Georgetown prison was erected in replacement of the krinting fence constructed, eighteen years earlier, on the order of the inspector of prisons on February 25, 1936.

\footnotetext{
$57 \quad$ Wright A. R. 1907, 426.

58 Ibid.

59 Beatty 1916, cited in Omasanjuwa A. intractable Pernicious Practices in West Africa Etnologia Actualis 28 (1), 2(2018), 5-26.

60 Ibid 2

61 Ibid 2, 4.
} 
With 19 cells and four association wards for male prisoners, the colonial Annual Report of 1909 described the prison system as not so good as could be wished but sufficient to meet the demands of the colony. In 1903, the prison accommodation facility was upgraded with the enlargement of more cells. However, separate system which was in force was not always enforced due to lack of sufficient space. At night, 3 or 4 prisoners occupies one ward. Such were the penal facilities at independence in 1965 . Virtually all the architectural structures were already obsolete at the dawn of the new dispensation, with inadequate plumbing and sewage systems, conditions which hindered the warders from performing their superintending responsibilities and upholding sanitary standards to the best of their ability.

Colonial prisons differed significantly from those that existed in Britain hence the use of the prison as a reformatory tool did not apply in the colonial context. ${ }^{62}$ The cosmetic efforts to upgrade the penal system were exercises in futility as nothing was accomplished to solve the recurring accommodation predicament in lockups and prisons where the ultimate goal was punishment and subjecting colonial subjects to conditions that violated fundamental rights. Also, the colonial authorities failed to acknowledge the degree of corruption in the system as manifested in the case of Mr. Travis while the draconian colonial economic measures and policies fuelled unemployment. Noteworthy is the shoestring budgetary allocation to the prison department which is incomprehensible. A fraction of the income generated from groundnut sales, for which the colony was reputed, would have been sufficient to at least ameliorate the desolation that plagued the penal system (See Appendix 1(a) and 1 (b)).

Rather than addressing issues bothering on public welfare in a land of devastating poverty and misery, the colonial administrators spent $£ 1,100$ in 1921 on constructing tennis courts for European use, while the goals of the prison service remained punishment and deprivation of offenders. ${ }^{63}$ Most of the youths who took to crime was partly caused by the collapse of the traditional economy and system with the introduction of an alien economic order which did not prepare them to compete on favourable terms with the outside world, from which they were ostracised. Groundnut prices, for example, and those for imported groundnut products were fixed by the colonial administrators in collaboration with British trading concerns. Information contained in the annual reports on colonial Gambia demonstrates how the colonial authority unambitiously could not, probably intentionally, address the symptoms of a penal system that remained obsoleted from its onset let alone tackling the causes of the social economic predicaments afflicting the colony.

In self-defence of the scanty European population in the colony, the decrepit prison condition was the colonialist's perception of playing it tough on crime as a means of scaring potential offenders. In 1851, there were only 190 Europeans in the colony. By 1939, at the commencement of WW II, the European staff strength was 57, which eventually plumped to 52 as the war progresses. ${ }^{64}$

62 Ibid 4, 103.

63 Cso 87/123. The Gambia National Archives File.

64 The Gambia National Archives file CSO 2/1989: Shortage of European Staff. 
The idea and practice of running prison facilities in the British fashion will remain alien to The Gambia as long as the preservation of the remnant local customs and traditions, battered by colonialism, remain high on the agenda of the post-colonial social order. Incarceration of offenders, from the Gambian perspective, remains out of tune with culture as the habit of caging human beings for reasons that can be resolved among contending parties is absurd and unconventional.

Imprisonment as introduced in colonial Gambia emphasised security and order in society, to the ultimate benefit of Europeans, in ensuring unobstructed supply of raw materials to Europe and their safety and security rather than reforming the prisoner.

After the visit of the Commission members to Mile 2 they went about their assignment of interrogating more witnesses as the forlorn call for reforms resonated in the public.

\subsection{Remarks.}

Salvaging Gambian prison facilities from its present state will unquestionably be arduous for the reason that prison reform incorporates a spectrum of disciplines which includes policy formulation and implementation, prison industry, prison hygiene, criminal procedure, prison economy, prison law, prison sociology, management, welfare, education, recidivism, etc. ${ }^{65}$ However, the necessity remains imperative hence society especially judges and social workers should develop interest in the prison system as it is the chief instrument by which criminal law is carried into effect, and consequently by which it must be judged. ${ }^{66}$

Conversely, embarking on an elaborate scheme as penal reform, amidst financial crunch, will be tantamount to funding a white elephant project, in the midst of want. Two years after the conducted tour, conditions inside Mile 2 and other detention sites and lockups remains dare, sharply contrasting international standards. This brings to mind plans that were afoot to erect a new prison building on an early date which will harmonise with modern principles. A promise made by the colonial Medical Director on August 10, 1957 which was indeed a repeat of the proposal of erecting a new prison in 1901 but could not commence on account of cost implication. As far as prison management is concerned there is no doubt that the post-colonial government and its antecedent are of the same stamp.

Sixty three years after independence, virtually nothing has changed. Besides, a country of less than two million inhabitants, with barely 700 people in detention, and per capita rate of incarceration of 31 per 100,000 does not need three distinct prison facilities. Unlike Seychelles with the highest per capita rate of incarceration in the world and the United States where an estimated $25 \%$ of adults have a criminal record, ${ }^{67}$ The Gambia is not a prison state, with $67 \%$ of its prisoners being of foreign extraction. The trend has been virtually the same since colonial times as contained in the notes of the colonial secretary in January 1948 where it was recorded that most

65 Gillian J. L. "The World's training School for prison officials" American Institute of Criminal Law and Criminology(1932-1933)

66 Ibid 13, 22

67 John A. Humbach "Is America Becoming A Nation of Ex-Cons?" Ohio State Journal of Criminal Law. (2015) 605 
of the convicts were aliens who had been convicted of theft. ${ }^{68}$ Contrariwise, it is doubtful if those in authority will appreciate the point of view of the reformists. The post-colonial government's determination to retain the colonial penal structure, for whatever reason, has partly led to what could be perceived as a jealous preservation of the dilapidated buildings.

Scanty information on what lay behind the walls started permeating public attention during the early years of the Yayah Jammeh administration, when members of the upper echelons of society started acquiring the least predictable appellation of civil detainees. These were those calling the shots in society before Yayah Jammeh military coup of 1994 that ushered him to power. The pre 1994 powers-that-be ensured that prison conditions remained perilous after independence. Contrary to the reason advanced by Andrew Coyle ${ }^{69}$ that government could not afford making them decent and humane, rather, they did not upgrade the condition because they, akin to the ex-colonial masters, felt that prison population was composed of mainly the economically and educationally underprivileged and marginalised class, illiteracy rate nationwide was $62 \%$.

The prison and other detention facilities started grappling with a deluge of problems and issues affecting those of both the upper and lower strata of society when during Yayah Jammeh's administration, The Gambia Love Affair with prison became manifest, placing her in category five of Andrew Coyle classification. ${ }^{70}$ Detention facilities were put to use in addressing issues having no bearing with crime, and detainees were punished with harsh prison conditions, especially accommodation facilities, for matters unrelated to crime. ${ }^{71}$ Most of the issues which should be outside the sphere of the criminal justice system came within the purview of state security agents. These led to excessive use and abuse of pre-trial detention, and even detention without trial. The Truth, Reconciliation, and Reparation Commission was acquainted with previously unspeakable testimonies from civil detainees who spent close to a decade in detention, without trial, for what they obviously knew nothing about. Ultimately, it escalated the problem of overcrowding and rights abuses as available prison accommodation facilities were stretched beyond limit. In principle, Abiodun Folarin asserts, detention of suspects awaiting the outcome of investigations/trials is no abuse provided it is under adequate environment and for a reasonable period, in the absence of other alternatives. As there was no clear cut empirical yardstick for defining what constitute abuse, adequacy of environment, and reasonable duration, detainees and convicts were exposed to gross abuse some of which were disclosed at the commission. Therefore, as the prison conditions have all along been shut from public view, it became imperative for the forlorn cries for reforms to, at any rate, receive some attention. The administration of former president Jammeh grappled with unprecedented widespread plea of its adversaries to the international community for assistance to address the dilemma. The meagre annual budgetary allocations to the Interior Ministry, as the authorities appeared to make the jail houses nauseating for those perceived to be dregs of society, fuelled the misery. Besides, akin to the colonial fashion, political detainees were in some cases accused of trump up charges to keep them out of circulation, somewhat for electioneering reasons, like criminals therefore deserving to spend time behind bars. Ever increasing number of

68 Colonial Secretary's Office--- Native Prisons (Protectorate) File ARP/2/1535. Gambia National Archive Banjul, Banjul, The Gambia.

69 Ibid 22, 826

70 Ibid 22, 828 .

71 Ibid 22, 828 
inmates awaiting trial resulted in a shortage of police investigators and prison personnel as well as magistrates, with the criminal justice system stretched to its limit. The importation of judges and other legal personnel to ease the work load in the courts could not ameliorate the desolation as they were perceived as mercenaries, on behind the scene stipends, to enable them compromise their professional integrity.

It is the abuses, essentially not the dilapidated architectural structures per se, that sparked the calls for reforms and international intervention to make the unpopular regime more detested. However, Just as mild trepidations in the law can complicate problems, amendment of the criminal law could offer opportunity to at least ameliorate a bad situation ${ }^{72}$ Cases demonstrates that institutional reforms are not new to The Gambia. In 1958, the old Royal West African Frontier Force (WAFF) was replaced by a smaller and cheaper unit named The Gambia Field Force, which was security reform, first of its kind in West Africa. The paramilitary unit was deployed periodically to quell urban disorder and to supervise elections, an arrangement that served the country's needs for over two decades before a national army was formed by the Gambia Armed Forces Act of 1985. The education and the civil service sectors were at various times reformed, besides the ongoing security sector reforms embarked upon by the successor of Yayah Jammeh. Therefore, if other sectors of the society have been overhauled, the prison situation deserve at least some attention.

Penal reforms took different forms in various societies for diverse reasons. ${ }^{73}{ }^{74}$ However, the pent-up Gambian penal reforms is implausible to yield expected results in isolation of the entire criminal justice system. ${ }^{75}$ This fact was also revealed in the former Soviet Union, and other states Andrew Coyle classified in category three. ${ }^{76}$ The police, and other crime detection and prosecuting agencies must be integral part of the arrangement, as well as judges and magistrates. Its success cannot be divorced from a steadfast political and legislative drive. ${ }^{77}$ Also, members of the public needs concrete assurances that the exercise will not jeopardise public safety and security; as making the prison conditions too comfortable could escalate recidivism. ${ }^{78}$

Unlike Latin American prisons where violence has necessitated calls for reforms, the call for improvement in prison conditions in The Gambia is motivated, inter alia, by the enduring neglect since 1821 that was exposed during the conducted tour of Mile 2 prison. ${ }^{79}$ In the United States whose legal system is based on common law precepts as The Gambia, judicial intervention has been positive in the running of prisons ${ }^{80}$ However, akin to the opinion of U.S. judge Morris Lasker, prison reforms cannot be accomplished through litigation as the Gambian society is not disposed to resolving issues of this nature through court processes. ${ }^{81}$ The amount of scarce resources a

72 Ibid 67,611

73 California Historic Reforms Public Policy Institute of California. (2016)

74 Ibid 16).

75 Andrew Coyle Prisons in a Time of Change." International Centre for prison studies U.K., (2002) 35-38. Cited In ibid 22.

76 See Yuri Ivanovich Kalinin The Russian Penal System: Past, Present And Future (2002), 23.

77 Lesker E. Morris “Prison Reform Revisited: A Judge’s Perspective.” 24 Pace Law Review 427. (2004)

78 Ibid 75,827

79 Ibid 79.

80 Nathan, Vincent, M. "Have the courts made a difference in the quality of prison conditions?” (2004)

$81 \quad$ Ibid 77,431 
comprehensive penal reform, which is likely to incorporate expanded prisons will gulp, it must be born in mind, will indirectly impact on the lives of law abiding citizens. The fact that the tax payers will bear the brunt justifies the attention of an alternative approach to the problem, if prison reform is avoidable.

The introduction of the culture of incarceration to The Gambia is ironical as it was an alternative designed to reform the indigenous solutions to the problem of crime and criminality, identical to the Sierra Leone experience; rather than enhancing colonial and post-colonial ulterior agenda. However, the effort has hitherto failed as the expected results still eludes the country after two centuries of floundering! The goals of the pre-colonial order encompassed compensation and reconciliation instead of caging offenders in dilapidated vicious structures. In a society as The Gambia with convoluted filial relationships, prisons should not be tools for resolving contentions, particularly those with the colouration of social problems, a characteristic associated with the fourth block of countries with prison rate between 30 and 100 per 100,000. Prison should be a place of last resort. The same applies to The Gambia where the prison population rate is 31 per 100,000 , not because of social infrastructures in form of welfare packages to cushion the effects of unemployment, but for the closely knit nature of the society which placed it in the same prison ratio bracket as Western European countries. The fashion in which society is imbibing and becoming malleable to Western influence, is likely to have the same effect on the incarceration ratio the way war on drugs is ravaging the category four countries. Prison population, for this reason, is likely to soar in good time hence precautionary measures should be in place.

As it will be easier, thus more convenient, to erect new prisons than rehabilitating the moribund structures, reforming the penal system could be an exercise in futility, considering the age long desolation and the demographic changes coupled with enhancement in educational standards. ${ }^{82} \mathrm{~A}$ more refine approach to the problem is required because reforming obsolete architectural structures, either through renovation or erecting new prison yards and holding facilities is not sustainable so long as the courts have extensive latitude of capacity to fill them while the meaning of crime is ever evolving, rendering the efforts futile..$^{83}$ Also, as long as a society shuts its eyes to the causes of crime, which make laws and penalties and prison institutions indispensable, there will be no end to law-breaking, no matter the number and quality of prisons it erects. ${ }^{84}$

The Gambia Prison population stood at 691 in 2019, while the official capacity of the three facilities is 650 and the prison population rate was 31 per 100,000, based on estimated national population of 2.21 million at April 2019. ${ }^{85}$ The report further breakdown the composition of the incarcerated as follows:

$82 \quad$ Ibid 77.

83 Paterson on Prisons: Being the Collected Papers of Sir Alexander Paterson 26 (S.K. Ruck Ed., 1951).

84 Ibid $9,873$.

85 https://www.prisonstudies.org/country/gambia 
Juveniles

Foreigners
$1.3 \%$

$66.7 \%$

$22.2 \%$.
8.983

460.897

153.402 .

The post-independence government's tongue in cheek to overhaul the system is yet to yield results as the desire has become a recurring decimal during annual budget speeches, with essentially no follow-ups. In view of the numerous challenges postcolonial Africa is grappling with, it is understandable why prisons remain neglected on the infinite list of scale of preference. ${ }^{86}$ It is no wonder therefore that prison systems are funded below par. ${ }^{87}$ In the 2019 Gambian budget speech, no reference was made to the prisons while the sector allocation to the host Interior Ministry was $3.37 \%$ of the budget. ${ }^{88}$ Despite the fact, in the 2020 budget speech, the ministry which also host the Police, and Immigration Services received 3.0\% of the sector allocations during which the Minister of Finance and Economic Affairs reiterated that the Ombudsman desire to visit prisons and detention sites and ensure that prisoners and detainees are kept in a favourable conditions and to make its findings and recommendations public. ${ }^{89}$ The meagre budgetary allocations brings to mind the shoestring expenditure on colonial prisons. In the 2021 budget speech, the Minister reiterated that the prison service will join forces with foreign partners to construct, refurbish and looking after the prison structures to the benefit of both inmates and officers. Plans in 2021 include the renovation of the Janjanbureh (Georgetown) Prison Centre; construction of rehabilitation centres for inmates to support reintegration of prisoners to prevent re-offending; update of the Prison Act; and the purchase of ambulances for referrals. ${ }^{90}$

Meanwhile, The Prisons Act no. 18 of 1953 which still form the legal basis of running the prisons, is an out-of-date instrument with no substitute for detention.

The UNDP assessment of prison and detention facilities exposed overcrowding in the Remand Wing and the main yard of Mile 2 and there was insufficient sleeping space. The inmates sleeps on wooden planks besides the overcapacity. To decongest the prison, some civil detainees were relocated to Jeshwang prison that was meant for low sentence inmates. Some inmates claimed to have been on remand for 5 years without charge. ${ }^{91}$

Anne Owen's claim is corroborated by the fashion the post-independence governments handled penal issues adding credence to her assertion that imported solutions has proved to be no solution.

Andrew Coyle asserts that in the prison world, efficient management is never sufficient. Hence, he is of the opinion that if one is doing the wrong thing at the outset, then efficient management

86 Jeremy, S. "Prisons in Africa: an evaluation from a human rights perspective" international journal on human rights, 5 (9), (2008)

87 Global Prison Trend Thailand Institute of Justice (2020).

88 https://mofea.gm > downloads-file > budget-speec...

89 https://www.mofea.gm > downloads-file > budget- ...

90 https://mofea.gm > downloads-file > 2021-budget..

91 https://info.undp.org/docs/pdc/Documents/GMB/Prison\%20report\%20final.pdf 
simply connotes that one will end up doing the wrong thing more efficiently. ${ }^{92}$ Reforming the defective fashion in which prisoners' accommodation issues have been handled since 1821 will be tantamount to doing the wrong thing with refined efficiency. Gambian penal problems are of a nature that does not require imported solutions, hence if a brand of reformation solved prison problems elsewhere, it does not follow that it will be amenable to Gambian situations. Upgrading the professional capability of the prison personnel to enhance competence without change of modus operandi, is likely to be an exercise in futility, as it will be synonymous to doing the wrong thing more efficiently. Andrew Coyle ${ }^{93}$ further stressed that the maintenance of security and good order does not imply the need for brutality and inhumanity. What The Gambia need is a system that will guarantee a further reduction of the low per capita rate of incarceration, not a well ordered prison system that has been defective from its onset. A criminal justice system should prop the values of society, but not be a substitute. ${ }^{94}$ The Gambian penal system has no locus hence the protracted forlorn cries for reform. Little evidence if any exist from anywhere in the world that levels of imprisonment, whether high or low, have any influence on levels of crime. ${ }^{95}$ This is substantiated by the Thailand Institute of Justice which asserts that the levels of crime is not proportional to the number of people in prison. ${ }^{96}$ The low crime level in The Gambia has no correlation with the obsolete prison facilities the country maintains, probably with the intention to scare and reprove potential offenders. It is therefore inaccurate to believe that it is by keeping prisoners in decrepit conditions that will transform them to be law abiding. Also, building more prisons or expending existing facilities, or better equipping the warders with modern professional knowledge of penology are not viable solutions to the problem of congestion at Mile 2 prison. Savings on education, for example, is likely to lead to the expansion of the prisons in less than no time. The causes of crime are not within the confines of prison yards hence the solution should be sought outside their premises. Wherever the problems are, that is where the therapies should be applied.

Byer's opinion that crime will never be cured nor law breaking be controlled by all the prisons a society can muster, as long as eyes are shut towards the causes that make laws and penalties and institutions indispensable, is realistic. ${ }^{97}$ Unquestionably, the prison system in Britain was ranked among the best in the world by penologists. ${ }^{98}$ This is attributed partly to the substantially improved socio economic conditions in the society which tumbled crime rate. ${ }^{99}$ Furthermore, courts, specialists, psychologists, and physicians should collaborate in finding solutions to the problem of crime. ${ }^{100}$ As long as prisons facilities in The Gambia are unsuitable for checking crime or reformation, the problem of crime will remain enduring.

$\begin{array}{ll}92 & \text { Ibid 22, 830. } \\ 93 & \text { Ibid 22. } \\ 94 & \text { Ibid 22, 831 } \\ 95 & \text { Ibid 22, 831 } \\ 96 & \text { Global Prison Trend Thailand Institute of Justice (2020). } \\ 97 & \text { Ibid 4, 413. } \\ 98 & \text { Ibid 13,22 } \\ 99 & \text { Ibid 13, 23 } \\ 100 & \text { Ibid 4, 873. }\end{array}$


Prison reforms are aimed at crime prevention, stopping the production of criminals and ultimately abolish prisons. ${ }^{101}$ However, proponents of reform in The Gambia should acknowledge that their clamour has implications on law enforcement, the penalties and the adjustments of offenders. The sort of society a people wished to build determines the level of imprisonment. ${ }^{102}$ As the traditional fabrics of the Gambian society is been slowly weathered by Western civilisation, there is need to be futuristic in the manner the issue of imprisonment is being handled as future generations will wonder over what transpired under the facade of dispensing justice. ${ }^{103}$ Gambian penal history shows that there has never been a well thought out plan to construct modern prison facilities in her entire history. Hence nothing has been accomplished in more than two centuries of attempts to provide liveable conditions in any of the prisons. Georgetown prison was a health facility transformed into a prison yard. The same applies to the central prison at Mile 2 which was formally an isolation hospital adapted to a prison in 1920. While the latter was at McCarthy Square from 1821 till 1920, it was indistinguishable from other public buildings in its neighbourhood, as it was in no perceptible way shaped by the demand of contemporary penology. Jeshwang prison, established in 1952 had a general renovation of all its buildings in 1955 due to leaks on nearly all the buildings at the camp; estimates was approved for a general re-roofing of the buildings in $1956,{ }^{104}$ owing to architectural defects.

\section{Result/Recommendation.}

An unprecedented novel colonial initiative which served its purpose was the demobilization of the old WAFF which The Gambia Field Force supplanted. A similar solution will address the problem of the neglect induced decay of the prisons. In the light of the foregoing discussion, either retaining or reforming the penal system and its structures will be tantamount to efficient perpetuation of centuries old wrongs by doing the wrong things more efficiently. Therefore, the existing prison yards, should be replaced by a unique arrangement, as it was the case with the defunct WAFF. The prison facilities should be phased out and the wreckages should be among the repertoire of the national museum for posterity. In replacement, an adult character transformation institution, under the aegis of the education ministry should supplant the dungeons. With $67 \%$ of prisoners in The Gambia being of foreign extraction, all non-indigenes convicted of transgressions should be deported to their countries of origin where they will serve their sentences. With the exception of special cases which should warrant a pre-clearance of a magistrate to examine special cases and circumstances, such deportees should be permanently barred from returning. This is to ensure government compliance with strict test of constitutionality. As criminal law has the capability to reform a society, a legislation in the cast of the Repatriation of Convicted Aliens Ordinance of 1924 and the Immigration Restriction Ordinance of 1924 should be enacted to keep away both undesirable immigrants. The transformational infrastructure which should have a section for lifers and those society considers irredeemable, including the special cases, should be managed by the education authorities with the assistance of the police, where the later considers it indispensable.

\footnotetext{
$101 \quad$ Ibid 4.

102 Ibid 75,823

103 www.oas.org/es/cidh/ppl/actividades/seminario2011/Coyle.pdf · PDF file

104 The Gambia Prisons Annual Report 1955. Gambia National Archives. ARP 19/4.
} 
Secondly, as it is not worthwhile reverting to the pre-colonial state of affairs, significant changes has to commence with an examination of the criminal and other laws and policies that has been glossed over since the colonial times. The Gambia is a signatory to a number of international treaties aimed at protecting the right of prisoners; they should be enforced to yield desired results rather than hoping to achieve the same end as countries that abide by the treaties which local public officers and policy makers are disregarding. The problems posed by the outdated colonial laws that still form the basis of regulating states of affairs in the country should be among the priorities of the Gambia Law Review Commission. It is essential because the way crime is defined by society largely determines if a prosecutor will secure a conviction or not in court. It must be admitted that no single law or action of the previous and present governments is responsible for the state of affairs. Rather, it is a product of a general lackadaisical attitude, among public officers, to public affairs and interests.

Lastly, Convicts deemed necessary to undergo reformation should, by law, be enrolled at the proposed institution to receive reformatory lessons in lieu of their sentences. There, psychologists in corroboration with other specialists, will remould their characters to enable them resist recidivism, for the benefit of society. It is essential as those serving time in The Gambia, from the look of things are denied adequate legal protection at least as far as provision of adequate accommodation facilities is concerned, a violation of fundamental rights. For pecuniary reasons, expanding the prisons, though permissible by law should not be an option. As more should be done to moderate dependence on incarceration, provisions should be enacted to avail senior citizens, septuagenarians and above, to serve non-custodial sentences provided arrangements are in place to provide adequate surety to guarantee keeping their side of the bargain. However, to ensure the success of the scheme, the institution should be headed and run by educationists while the staff, especially the warders of the disbanded prison service, should receive training in education, to empower them to blend with the transformation. By implication, the interior ministry will be relieved of its responsibility to managing the prison service.

The Gambia penal policies has been punitive and vicious without cause hence an alternative arrangement is vital by reason of the convoluted filial relationships of the social order. As the fundamental European prison philosophy contravenes Gambian customary values, the novel arrangement will be a better substitute that places higher worth on reconciliation and cohesion among contending parties, rather than retribution.

\section{References}

Abiodun, Tosin Fumi. A historical study on penal confinement and institutional life in southern Nigeria, 1860-1956. Ph.D. dissertation, University of Texas at Austin, (2013), 1-405

Alemika, E. "Socio-economic and Criminological Attributes of Convicts in Two Nigerian Prisons," Journal of Criminal Justice 16, (1988).

Andrew, C. Managing Prisons in a Time of Change. International Centre for prison studies U.K. (2002), 1-110 https://www.prisonstudies.org/sites/default/files/... PDF file.

Andrew, Coyle. "Prison Reform Efforts Around The World: The Role OfPriso Administrators," 24 Pace Law Review (2004), 825-832 
Anne, Owers. "Prison inspection and protection of prisoners right," 30 Pace Law Review 1535, (2010). 1535-1547

Archer, Francis Bisset. "The Gambia Colony and Protectorate: An Official Handbook." (Frank Cass \& C. Ltd. 1967), 1-367.

Beatty, Kenneth James. "Human Leopards: An account of the Trials of Human Leopards before the Special Commission Courts; with a note on Sierra Leone, Past and Present." (London: Hugh Rees.1915), 1-234.

. Beatty, Kenneth James. Review by F.W.H.M. "Human Leopards Society” In Journal of the Royal African Society, 15, (59), (1916): 1-292. 873-884

Byers, P. Joseph. "Prison Reform", Journal of Criminal Law and Criminology, 872 (1916),

Charles A. Ellwood. "English Prison System and What We Can Learn from It," Journal of American Institute of Criminal Law and Criminology, (May 1916 to March 1917). https://www. jstor.org/stable/1133609 - PDF file

Cindy, S Wood. “Addressing Prison Overcrowding In Latin America: A Comparative Analysis of The Necessary Precursors To Reform." Journal of International C \& Comparative Law. 22, (2016), 533-560

Dior, Konate. "A History of the Penal State in Senegal: Repressive Architectures and the Life of Prison Detainees from the 19th Century to the Present," (PhD diss., University of Wisconsin.), (2006).

Elias, T. Olawale The Nature of African Customary Law”, 268. (1964).

Gillian, J. L. "The World's training School for prison officials" American Institute of Criminal Law and Criminology (1932-1933). 101

Global Prison Trend Thailand Institute of Justice (2020). https://cdn.penalreform.org/ wp-content/uploads/2020/05/Global-Prison-Trends-2020-Penal-Reform-International-SecondEdition.pdf

Jarrett, .Reginald "The Strangers-Farmers of The Gambia." Geographical Review, 39 (4). (1949). 649-657

Jeremy, S. "Prisons in Africa: an evaluation from a human rights perspective" international journal on human rights, 5 (9) (2008). 22-49.

John, A. Humbach. "Is America Becoming A Nation of Ex-Cons?" 12 Ohio St. Journal of Criminal Law. $605-612$

Kristin, Mann, Law in Colonial Africa (London: Heinemann Educational Books), 1-264

Lasker, E. Morris “Prison Reform Revisited: A Judge's Perspective." 24 Pace Law Review 427. (2004).427-431.

Lasker, E. Morris. "Prison Reform Revisited: The Unfinished Agenda," 24 Pace Law Review 427. (2004 b) 395-417.

Leonard, K. The Kenya Penal System: Past, Present and Prospect Washington: (University 
Press of America 1981).

Michael, B. Mushlin. "I Am Opposed to This Procedure: How Kafka's In the Penal Colony Illuminates the Current Debate About Solitary Confinement and Oversight of American Prisons," 93 Oregon Law Review. 571. (2015).531-230

Nathan, Vincent . M. "Have the courts made a difference in the quality of prison conditions?" Pace Law Review. 419. (2004). 419-426

Omasanjuwa, A. Proposed "Convict Enfranchisement in the Gambia: Lessons from America," Journal of Universal History Studies, 3 (2), (2020). 168-194.

Omasanjuwa, A. and Phebean, J. "Public Health in Colonial and Post-Colonial Gambia: A case Study of Malaria Fever.” West Africa Review, Issue 24 (2014) 81-107

Omasanjuwa, A. "Pernicious Practices in West Africa". Ethnlogia Actualis, 18, (1). (2018) $17-41$.

Park, James. Matthew. "Heart Of Banjul: The History Of Banjul, The Gambia, 1816 -1965," A PhD Dissertation Submitted to Michigan State University. (2016). 1-403.

Paul, Osifodunrin. "Property Crime in Nineteenth Century Lagos: Criminal Tradition or Popular Culture of Accumulating Wealth," unpublished paper, (2010). 33.

Robert, Ringer. The Individual Versus the State. (2014). https://robertringer.com/individualversus-state/

Yuri, I, K. "The Russian Penal System: Past, Present And Future” (2002) 23.

Wright, A. R. "Secret Societies and Fetishism in Sierra Leone." Folklore, 18, (4) (1907). 423-427.

Zahid, A. S. and Zubair Shah "A History of Prison Reforms in Pakistan.” Global Regional Review, 1 (1). (2016). 35-47. 


\section{Appendix 1 (a).}

Export of Groundnuts and Prices per ton

Source: Extracted from Gambia National Archive file No. Cso 2/395.

West African Currency Board

Year. Tons Market price.

\begin{tabular}{|c|c|c|}
\hline 1912 & 64,196 & $==$ \\
\hline 1913 & 67,404 & $==$ \\
\hline 1914 & 66,885 & \\
\hline 1915 & 69,151 & \\
\hline 1916 & 46,336 & $=$ \\
\hline 1917 & 74,300 & \\
\hline 1918 & 56,490 & $====$ \\
\hline 1919 & 70,290 & $=====$ \\
\hline 1920 & 84,037 & 27.12 .00 \\
\hline 1921 & 58,273 & 10.12 .00 \\
\hline 1922 & 62,978 & 12.03 .00 \\
\hline 1923 & 62,564 & 13.12 .00 \\
\hline 1924 & 58,980 & 14.05 .00 \\
\hline 1925 & 46,583 & 14.03 .00 \\
\hline 1926 & 57,334 & 14.05 .00 \\
\hline 1927 & 65,107 & 14.01 .00 \\
\hline 1928 & 74,442 & 14.13 .00 \\
\hline 1929 & 56,355 & 13.11 .00 \\
\hline 1930 & 74,761 & 11.12 .00 \\
\hline 1931 & 66,811 & 07.11 .00 \\
\hline 1932 & 37,315 & 10.09 .00 \\
\hline 1933 & 67,370 & 07.08 .00 \\
\hline 1934 & 71,919 & $\begin{array}{lll}05 & .07 & .00\end{array}$ \\
\hline 1935 & 44,712 & $08 \quad .03 \quad .00$ \\
\hline 1936 & 49,104 & 08.12 .00 \\
\hline
\end{tabular}


e-ISSN 2458-7672

https://dergipark.org.tr/tr/pub/jhf
Tarih ve Gelecek Dergisi, Haziran 2021, Cilt 7, Sayı 2 Journal of History and Future, June 2021, Volume 7, Issue 2

$\begin{array}{lllll}1937 & 66,566 & 09 & .14 & .00 \\ 1938 & 46,651 & 05 & .14 & .00 \\ 1939 & 48,925 & 05 & .01 & .00 \\ 1940 & 39,188 & 06 & .07 & .00 \\ 1941 & 40,318 & 05 & .19 & .00 \\ 1942 & 15,651 & 05 & .19 & .00 \\ 1943 & 17,756 & 07 & .13 & .00 \\ 1944 & 27,538 & 10 & .06 & .00 \\ 1945 & 41,094 & 14 & .09 & .00 \\ 1946 & 37,772 & & ====== \\ 1947 & 54,245 & & ====== \\ 1948 & 70,500 & & ===== \\ & ==\end{array}$

\section{Appendix (1b)}

Allocations to The Gambia from The West African Currency Board form 1920-1944

Date Month Year Amount (pounds) $£$

$\begin{array}{cccc}17 & 07 & 1920 & 8,500 \\ 31 & 12 & 1920 & 4500 \\ 23 & 06 & 1923 & ==== \\ 11 & 01 & 1924 & 6,000 \\ 28 & 06 & 1924 & 6,000 \\ 09 & 01 & 1925 & 6,075 \\ 15 & 01 & 1926 & 5,071 \\ 07 & 07 & 1926 & 5,071 \\ 16 & 12 & 1926 & 4,715 \\ 13 & 07 & 1927 & 4,715 \\ 10 & 01 & 1928 & 5,815 \\ 26 & 07 & 1928 & 5,815 \\ 09 & 01 & 1929 & 6,196 \\ 09 & 07 & 1929 & 8,749 \\ 23 & 01 & 1930 & 5,162\end{array}$




\begin{tabular}{ccccc}
21 & 01 & \multicolumn{2}{c}{1931} & 5,126 \\
26 & 03 & 1931 & 2,886 \\
18 & 03 & 1932 & 2,886 \\
26 & 08 & 1932 & 2,702 \\
03 & 02 & 1933 & 5,404 \\
04 & 07 & 1933 & 2,173 \\
23 & 01 & 1934 & 8,616 \\
10 & 07 & 1934 & 3,154 \\
14 & 02 & 1935 & 4,713 \\
06 & 08 & 1935 & 2,492 \\
05 & 02 & 1936 & 2,492 \\
13 & 08 & 1936 & 2,192 \\
25 & 03 & 1938 & 2,002 \\
04 & 01 & 1941 & 3,330 \\
10 & 01 & 1941 & 1,325 \\
06 & $=$ & 1942 & 1,325 \\
12 & $=$ & 1943 & 1,601 \\
22 & $=$ & 1944 & 4,973
\end{tabular}

Source: Jarrett (1949:653). 
Appendix 2[B] Number of admissions to prison from 1895 to 1935 with some years missing

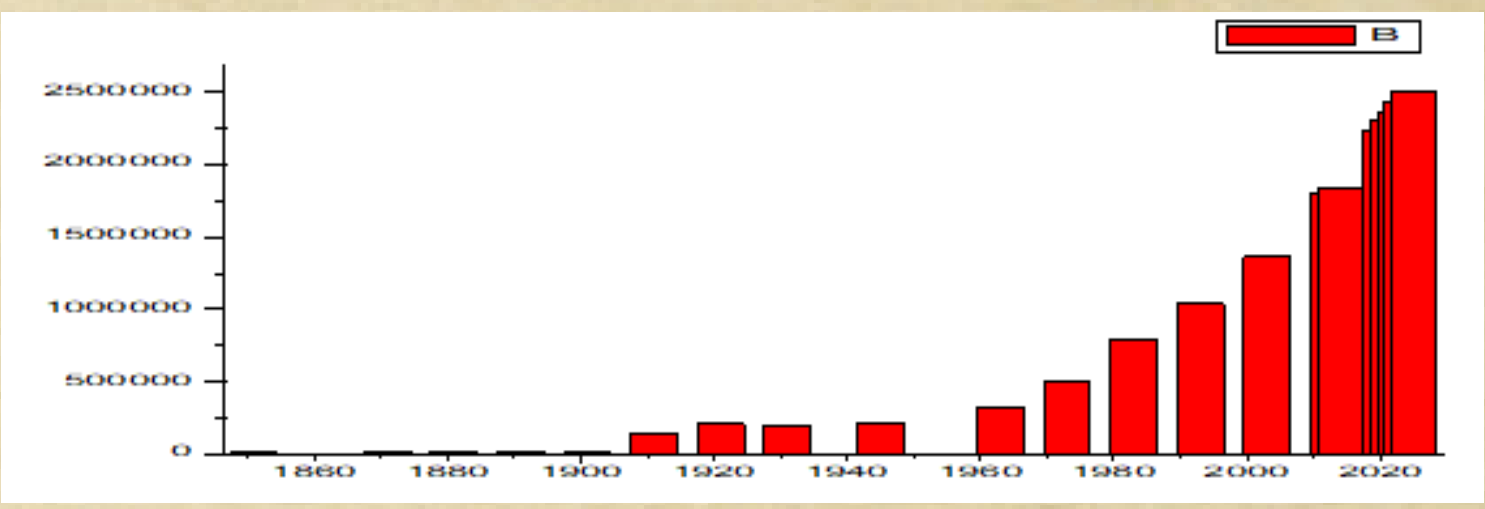

Appendix 2[A] Population increase from 1851 to 2013 and projection from 2014 to 2025.

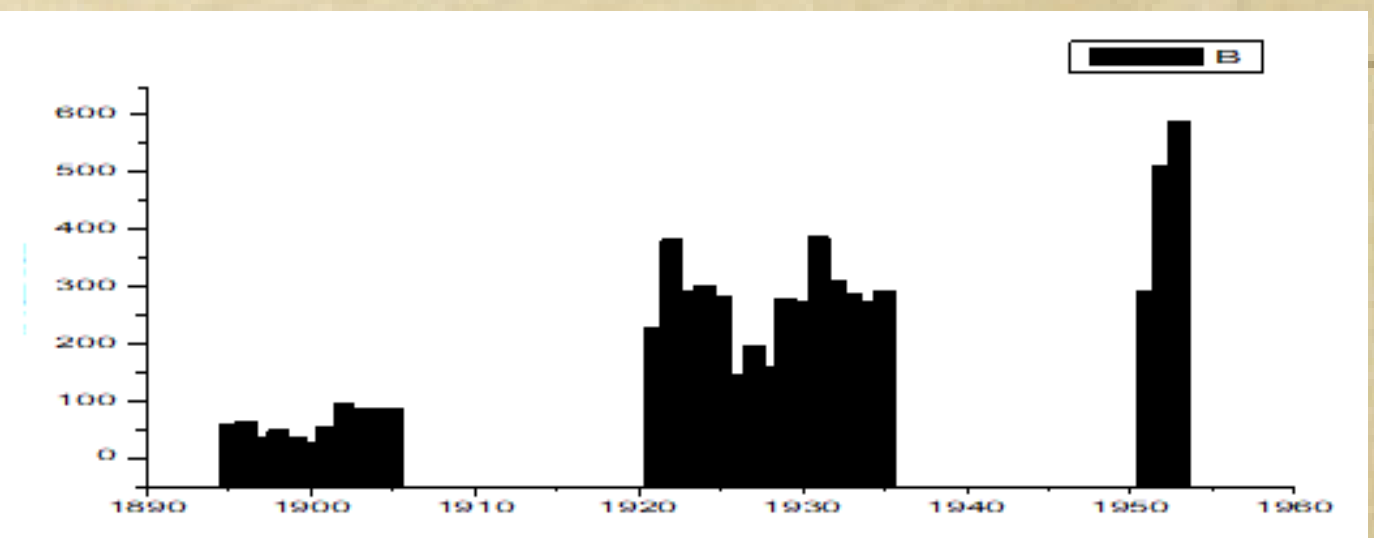

